\title{
Uddeling af Danmarks Geologipris - til professor Minik Thorleif Rosing
}

\section{Af Henrik Højmark Thomsen, GEUS}

Danmarks Geologipris 2008 blev lørdag d. 14. marts tildelt professor Minik Thorleif Rosing fra Geologisk Museum, Københavns Universitet. Prisen på 25.000 kr. blev givet for hans enestående undersøgelser af nogle af Verdens ældste bjergarter ved Isua i Grønland, som har ført til banebrydende dokumentation af og teorier om Jordens tidlige udvikling.

I 2004 påviser Minik Rosing, gennem studier af kulstof i bjergarter fra Isua, at fotosyntese var i gang på jorden for mere end 3,7 milliarder år siden, og at der eksisterede liv langt tidligere end hidtil erkendt. Arbejdet fik en meget stor international opmærksomhed, og afhandlingen blev senere kåret som den mest citerede artikel fra 2004-2007 i tidsskriftet "Earth and Planetary Science Letters".

\section{Kreativ teori}

Og i 2006 publicerer han sammen med kolleger en teori, som beskriver, at de tidligste

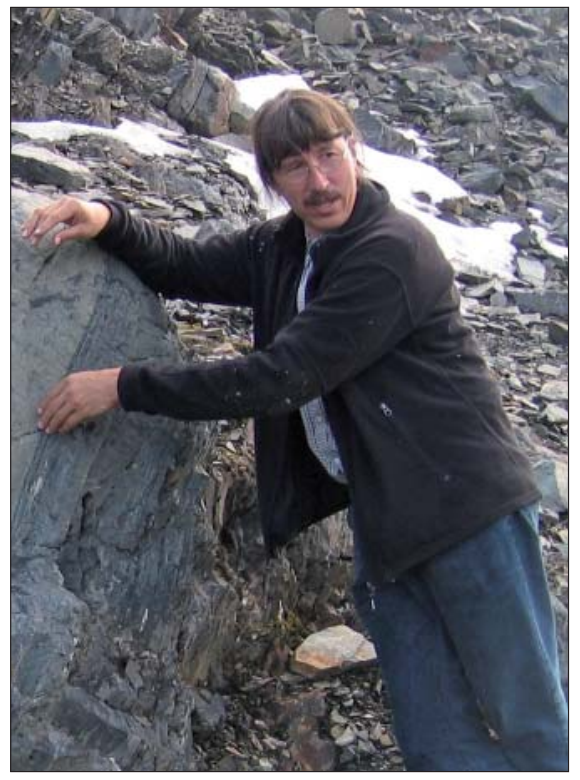

Modtageren af Danmarks Geologipris 2008, professor Minik Rosing viser nogle af Jordens celdste bjergarter frem ved Isua $i$ Vestgrønland. (Foto: Julie Hollis)

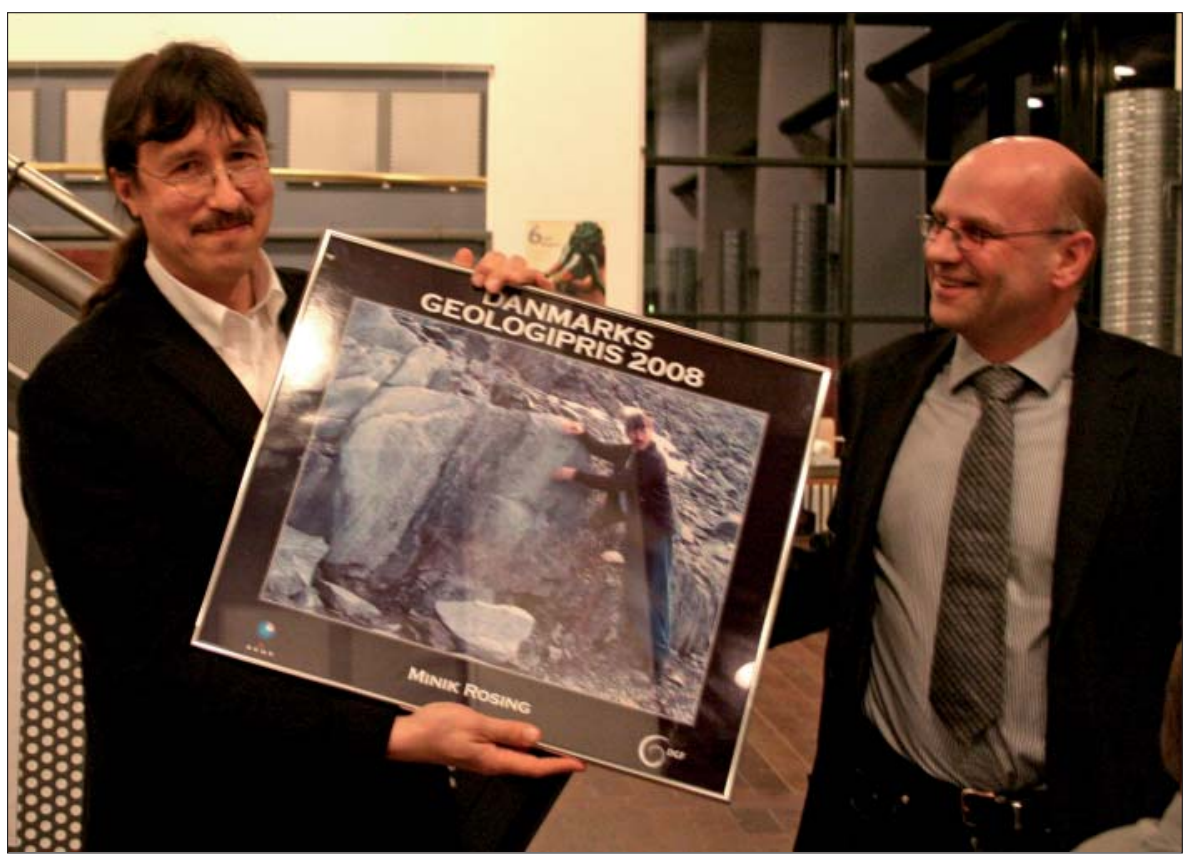

Minik Rosing til venstre modtager Danmarks Geologipris 2008 af vicedirektør Flemming Getreuer Christiansen fra GEUS. (Foto: Forfatteren)

levende væsner ved fotosyntese skabte den ilt som førte til dannelsen af granit, som er den væsentligste bestanddel Jordens kontinenter. Den udsædvanligt kreative teori, at livet har været med til at skabe Jordens kontinenter, trak overskrifter i alverdens medier.

Endelig er Minik Rosing i 2007 i en artikel i Science med til at påvise tilstedeværelsen af Jordens ældste ofiolitbjergarter ved Isua i Grønland, som fortæller, at pladetektonik og havbundsspredning foregik for 3.8 milliarder år siden.

\section{Vidtspændende formidling}

Minik Rosing er i international sammenhæng en centralt placeret forsker, og han er en af Danmarks mest citerede videnskabelige forfattere, som gør ham til et født medlem af flere kommissioner og videnskabelige råd. Hans formidling spænder vidt og rækker fra videnskaben til kunstens verden og dens vekselvirkning med geologi - senest i bogen "Verdensbillede - Geologi og Kunst" som han har udgivet sammen med maleren Per Kirkeby.

Minik Rosing har med meget stor gennemslagskraft skrevet talrige populærvidenskabelige indlæg og artikler i bøger, aviser og tidsskrifter, og han har derigennem frem- met kendskabet til og forståelsen af Grønlands geologi, som leverandør af enestående eksempler på Jordens udvikling.

Prisen blev overrakt af vicedirektør Flemming Getreuer Christiansen fra GEUS under årsmødet i Dansk Geologisk Forening på Geocenter København.

Ved overrækkelsen sagde Flemming Getreuer Christiansen: "Minik Rosing har på en helt unik vis brugt sin store viden om Grønland til international topforskning, til internationalt forskningssamarbejde og til en omfattende populær formidling. Han er en helt enestående ambassadør for Grønlands geologi og for geologien generelt."

Minik Rosing takkede for prisen og sagde: "Jeg er meget meget glad for at have fået Danmarks Geologipris. Det bedste man kan få er en pris fra sine kolleger”.

Danmarks Geologipris på 25.000 kr. uddeles én gang om året af De Nationale Geologiske Undersøgelser for Danmark og Grønland (GEUS) efter indstilling fra bestyrelsen for Dansk Geologisk Forening.

Prisen tildeles en person eller gruppe af personer, som inden for de seneste 5 år har publiceret én eller flere afhandlinger eller kort, der i særlig grad har bidraget til forståelsen af Danmarks eller Grønlands geologi. 